\title{
Carpal tunnel szindróma sikertelen kezelése „minimal invazív” eljárással
}

\author{
Esetismertetés
}

\author{
DR. RENNER ANTAL, DR. BAKTAI JÓZSEF, DR. SZENTIRMAI ANNAMÁRIA
}

\section{ÖSSZEFOGLALÁS}

A carpal tunnel szindróma a nervus medianus fokozatosan kialakuló kompressziós megbetegedése. Oka sokrétú lehet. A betegség, ha felismerték, konzervativ kezelésben részesült, az eredmény azonban többnyire súlyos motoros és szenzoros károsodás volt. A kezdeti mútéti próbálkozások a nervus medianus leszorítása okozta panaszokat megszüntették ugyan, de az akkori mútéti technika sok-sok hiányossága miatt, a tenyéri heg fájdalmas utópanasza hosszú ideig megmaradt. Optimális, teljes változást, a XX. században megjelenő korszerű kézsebészet jelentett, a tenyéri feltárásból végzett nyitott mútéti technika legtöbb esetben szövődménymentes, teljes gyógyulást eredményezett. Az utóbbi két évtized technikai fejlődése és számos egyéb tényező eredményeként megjelentek, s széles körben egyre gyakoribbá váltak az úgynevezett „minimál invazív” sebészi eljárások, amelyeket sajnos nem minden esetben kellő felkészültséggel alkalmaznak. Az endoszkópos és a fedett technikák kétségtelenül magas szövődményveszélyét a mútéti technika további fejlesztésével próbálják kivédeni, s ez a folyamat napjainkban is tart, mert az ideális „minimál invazív” módszert még nem sikerült megtalálni. Egy 60 éves férfi betegen elvégzett „minimál invazív sebészi kezelés" szomorú eredményét kívánjuk bemutatni, akinél 3 évvel korábban kezdődő panaszok miatt, fél évvel ezelőtt, a középső csukló barázdában ejtett 1,5cm-es, H-alakú metszésből, „minimál invazív" eljárással, a ligamentum carpi transversum behasítását és neurolysist végeztek, eredménytelenül. A reoperációnál a nervus medianus kettős leszorítását találtuk, a retinaculum flexorum transversum egyáltalán nem volt átmetszve, és a motoros ág maradványa sem volt megtalálható. A reoperáció után a beteg fájdalmai megszűntek, a szenzibilitás javult. Következtetésünk szerint elvárható szakmai minimum, hogy aki ilyen mútétre vállalkozik, teljes értékúen ismerje annak a régiónak az anatómiai felépítését, ahol operál. Előzetes tapasztalatszerzés nélkül, (cadaver gyakorlat, tanfolyam) ne vállalkozzon eredményességüket még nem bizonyított, új kezelési eljárás alkalmazására. Az eset kapcsán szeretnénk felhívni a figyelmet a Szakmai Kollégiumok által kiadott Szakmai Protokollok alkalmazásának, továbbá betartása ellenőrzésének fontosságára.

\section{Kulcsszavak: Carpal tunnel szindróma; Dekompresszió; Minimál invazív eljárások;}

A. Renner, J. Baktai, A. Szentirmai: Unsuccessful treatment of carpal tunnel syndrome with "minimally invasive" technique. Case report

The carpal tunnel syndrome is a gradually worsening disease of the median nerve caused by compression. It may have diverse causes, which cause stricture in the carpal tunnel. The disease, if recognized, was treated in a conservative manner, but it resulted in serious motor and sensory damage to the nerve in most cases. The initially applied surgical techniques resolved the patients' complaints resulting from compression, but a long-lasting, painful palmar scar remained due to the numerous deficiencies of the method. Up-to-date hand surgery brought an optimal, all-round change in the $20^{\text {th }}$ century; surgeries performed through an open palmar approach made complete healing possible without any complications in most cases. As a result of technical evolution in the last two decades and several other factors, the so called "minimally invasive" surgical methods became more and more popular and widespread, which were applied - unfortunately - without appropriate skills in some cases. Further development of techniques was intended to reduce the definitely high rate of complications after endoscopic and closed methods and this tendency is present even nowadays, because the ideal "minimally invasive” method is still missing. 


\section{BEVEZETÉS}

A carpal tunnel szindróma a nervus medianus fokozatosan kialakuló kompressziós megbetegedése. Oka lehet minden olyan elváltozás, amely térszúkítő folyamatot képez a tenyéri csatornában. A retinaculum flexorum - miután szerkezetéból eredően nem képes a megnyúlásra - fokozatosan erősödő leszorítás révén károsítja az ideget, ami erős tenyéri fájdalmat, szenzibilitás zavart, s egyes esetekben motoros károsodást - opponens izomsorvadást - is okozhat.

A kórkép első leírójának tekintett Sir James Paget 1854-ben két eset kapcsán számolt be radius distalis vég törés után kialakult nervus medianus kompresszióról $(2,22)$. Akkor az egyik betegnél amputációt végzett, a másik beteget „splint"-tel kezelte. A betegség, ha felismerték, konzervatív kezelésben részesült, az eredmény azonban többnyire súlyos motoros és szenzoros károsodás volt.

Az első mútéti feltárás leírása Sir James Learmonth-tól származik $(1933)(2,5,16)$. A kezdeti mútéti próbálkozások a nervus medianus leszorítása okozta panaszokat megszüntették ugyan, de az akkori mútéti technika sok-sok hiányossága miatt, a tenyéri heg fájdalmas utópanasza hosszú ideig megmaradt.

A sebészi technika részletes leírását $B$. $W$. Cannon és J. G. Love publikálta 1946-ban, 38 eset kapcsán szerezett tapasztalatuk alapján, ők már a retinaculum flexorum teljes átmetszését végezték (2).

A kórképet nyomtatásban megjelenő publikációban elsőként $M$. Kremer nevezte carpal tunnel szindrómának (1953) (2).

Optimális, teljes változást a XX. században megjelenő korszerű kézsebészet jelentett, mert az új, komplex, atraumatikus mútéti technika, a modern bőrvarró anyagok, a korszerü posztoperatív sínrögzítés minimálisra csökkentette a mútét után jelentkező panaszokat, $s$ az ideg leszorítottságának időtartamától függően kitűnő regenerációt eredményezhetett. A pontosan diagnosztizált, EEG-vel igazolt carpal tunnel szindróma (CTS) a tenyéri feltárásból végzett nyitott mútéti technikával (Open Carpal Tunnel Release/OCTR) a legtöbb esetben szövődménymentes, teljes gyógyulást eredményezett $(14,22,25,26)$.

\section{A mútét szakaszai}

- longitudinális feltárás az ideg kritikus szakaszán,

- a retinaculum flexorum teljes és biztonságos átmetszése szem ellenőrzése mellett,

- a comprimált idegszakasz mobilizálásával keringésének javítása,

- az alkari fascia distalis végének behasításával a proximalis leszorítás megszüntetése, ha szükséges,

- az esetleges krónikus synovitis szövettömegének excisiója,

- végül az ideg motoros ágának ellenőrzése az opponens izom szélénél, az esetenként itt is előforduló direkt fascia leszorítás oldása

- bőrvarrat

Fenti mútéti lépések összessége a szem kontrollja mellett, kizárólag a hosszirányú feltárás alkalmazásával végezhető el!

Az utóbbi két évtizedben a technikai fejlődés és számos egyéb tényező eredményeként megjelentek, s széles körben egyre gyakoribbá váltak az úgynevezett „minimál invazív” sebészi eljárások (1, 4, 5, 6, 15, 19, 23). Az endoszkópos és a „Knifelight” mútétek, az ultrahang-aszszisztált percutan fedett átmetszés, a "short incision technique", és a kettős rövid metszés alkalmazása. Az egészségügy takarékossági megfontolásai, az „egynapos sebészet” lehetőségeinek bővülése, a magánklinikák egyre növekvő száma, a kellő mélységú kézsebészeti ismeretekkel nem rendelkező „manuális szakmákat” múvelők érdeklődésének növekedése oda vezetett, hogy mindezzel párhuzamosan megjelentek a „minimál invazív” sebészi kezelések ötlet-variációi, új és még újabb vonzó mútéti típusok $(7,8,10-13,17,18,23,24,26)$, amelyeket az egynapos sebészet keretében „futószalagon”, „utcán át” alkalmaznak, úgy az állami betegellátás, mint a magánkórházi, illetve a magán egynapos sebészeti gyakorlatban, sajnos nem minden esetben kellő felkészültséggel. A CTS 
mind gyakoribb felismerése pedig a CTS „népbetegség" látszatát keltheti.

Nem kellett azonban sok évnek eltelni, s megjelentek a különböző módszerek szövődményeit, azok gyakoriságát összehasonlító őszinte hangú kongresszusi előadások, és közlemények, amelyekből kiderül, hogy az endoszkópos mútétek drágák, igen hosszú a módszer elsajátításának tanulási ideje, és olyan súlyos szövődmények is létrejöhetnek, amelyek a klasszikus longitudinális feltárások alkalmazása során gyakorlatilag nem fordulhatnak elő! Ezért helyette különböző „minimál invazív”-nak nevezett fedett technikák alkalmazásával próbálkoznak, ahol a kétségtelenül magas szövődményveszélyt vagy a bevezetett eszköz bőr alatti megvilágításával, vagy a mútét menetének ultrahangos követésével, vagy több apró metszés alkalmazásával próbálják kivédeni $(3,6,19,20,25,27)$. Ez a folyamat napjainkban is tart, mert az ideális „minimál invazív” módszert még nem sikerült megtalálni.

Egy 60 éves férfi betegen elvégzett „minimál invazív sebészi kezelés" szomorú eredményét kívánjuk bemutatni.

\section{ESETISMERTETÉS}

B. Z. 60 éves, erős testalkatú, fizikai munkát végző férfi beteg. Anamnézisében mútéttel kezelt duodenalis ulcus szerepel. Bal kezén 3 évvel ezelőtt kezdődtek a carpal tunnel szindrómára utaló panaszok, majd kialakult a klasszikus tünetegyüttes. Fél évvel ezelőtt egy vidéki város sebészeti osztályán - vizsgálata után - felajánlották a mútéti beavatkozást, amelyet a beteg elfogadott. A kórházi zárójelentés szerint: „ligamentum carpi transversum behasitást, neurolysist végeztünk helyi érzéstelenítésben". A tünetek, panaszok azonban nem szűntek meg, a mútét eredménytelen volt.
A beteg, a kéz rosszabbodó és állandósuló fájdalmas panaszaival - interneten informálódva - kereste fel intézetünket, s kérte orvosi véleményünket.

Felvételi státusz: „a bal csuklón, palmarisan, a középső csuklóbarázdában, mintegy $1 \mathrm{~cm}$-es $\mathrm{H}$-alakú hegvonal (1. ábra). Mind a hegvonalak, mind a carpalis csatorna vetületében a bőr fájdalmas. A nervus medianus területén a bőr száraz, szem kontrollja nélkül az erősebb bőringerek helyét is téveszti. A vizsgálati tesztek pozitívak, megerősítik a carpal tunnel szindróma jelenlétét. $\mathrm{Az}$ opponens izom teljesen elsorvadt, de a thenar területe oedemásan duzzadt. Vizsgálatnál az említett fájdalmak fokozódnak. Az EMG vizsgálat megerősítette a carpal tunnel szindróma fennállását."

Mivel az észlelt tünetek megerősítették a feltételezést, hogy a Sebészeti Osztályon korábban elvégzett mútét nem szüntette meg a panaszok okát, ismételt mútétet ajánlottunk, amit a beteg elfogadott.

A mútét menetét tudatosan fotóztuk! A teljesen ép, viszont rendkívül megvastagodott, retinaculum flexorumot, apró szakaszokban vágtuk át - Freerrel védve az ideget. $A$ retinaculum flexorum átmetszése után a nervus medianust környezetéhez préselve, letapadt állapotban találtuk, két helyen leszorítva, közte mintegy "feltorlódva” (2-3. ábrák). A további lelet már nem volt meglepetés. Az opponens izom elsorvadásának oka, hogy a motoros ág maradványa sem volt megtalálható!

Kíméletesen oldottuk környezetéből az ideget (4. ábra), majd drain fölött 5/0-s fonallal, csomós varratokkal zártuk a bőrt. Két hétre, a varratok eltávolításáig dorsalis alkarsínen nyugalomba helyeztük a mútéti területet. Zavartalan sebgyógyulás után szakszerű utókezelést végeztettünk.

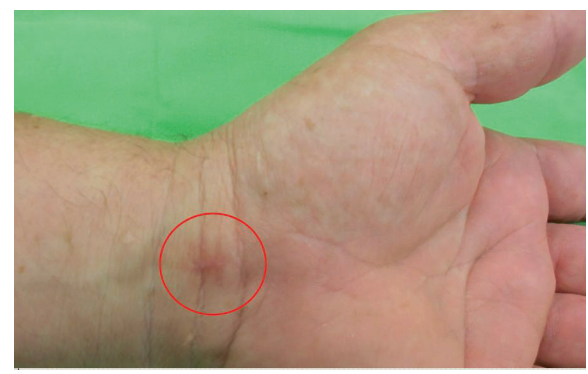

1. ábra A három évvel korábbi mütét hegvonala $(4-5 \mathrm{~mm})$ a ligamentum carpi volare vetületében. 


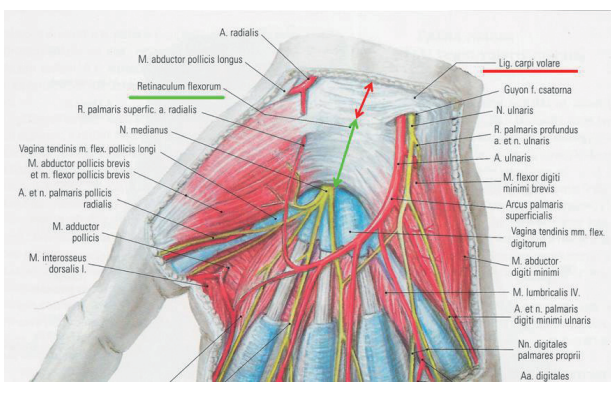

2. a ábra

A három évvel korábbi mútétnél a ligamentum carpi volare behasítása történt (piros nyillal jelölt terület), mert „itt domborodott elo" az oedemás nervus medianus. $A$ leszorítás ettől distalisan volt, az nem került átmetszésre. A reoperáció során a retinaculum flexorum átmetszését végeztük (zöld nyillal jelzett terület).

(Rajz: Tömböl Teréz: Tájanatómia, 18. ábra)

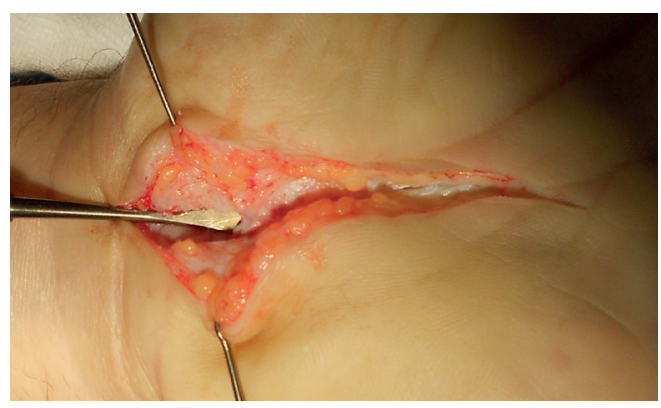

3. a ábra

A retinaculum flexorum proximalis széle alá, az ideg fölé vezetett fém védőeszköz, amely mentén szakaszosan vágjuk fel a retinaculumot.

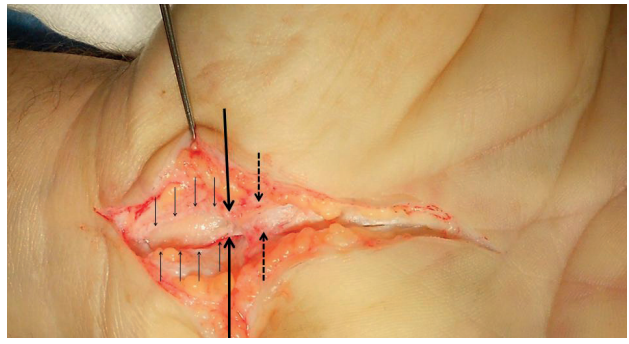

\section{2. b ábra}

A börmetszés után jól láthatóvá vált a korábbi mütétnél átmetszett ligamentum carpi volare alatt szabadon lévő, oedemás, megvastagodott nervus medianus (apró fekete nyilak között). A két vastag fekete nyíl jelzi a nervus medianust mintegy "lefüzö" retinaculum flexorum proximalis szélét. Ettől distalisan a retinaculumot „elödomborítja" a duzzadt nervus medianus (szaggatott nyíl).

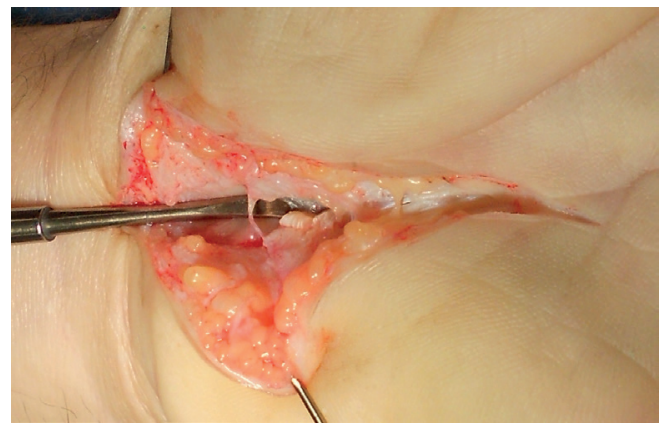

\section{3. b ábra}

Az első metszésnél a proximalis szél néhány rostját a jobb demonstrálhatóság érdekében megtartottuk.

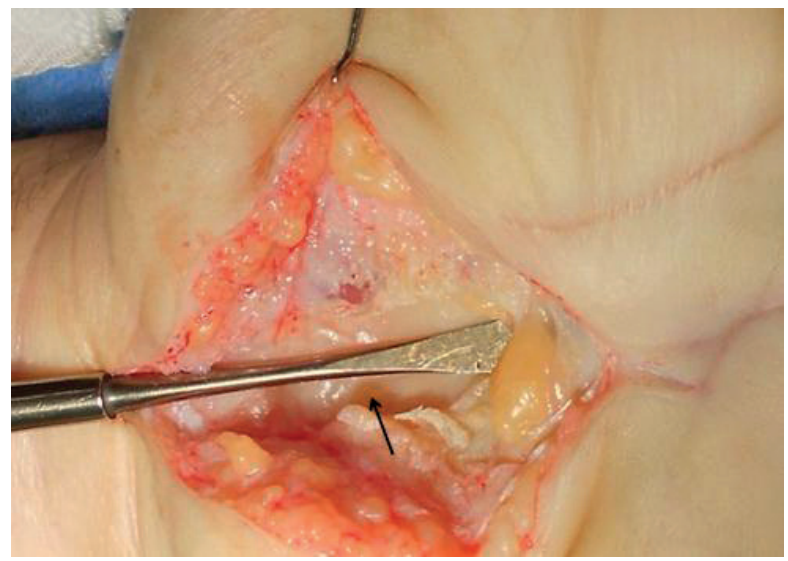

\section{3. c ábra}

A retinaculum flexorum teljesen átmetszve. Már ezen a képen is látható a valódi leszorítás helye (fekete nyíl), s töle proximalisan a duzzadt nervus medianus. 


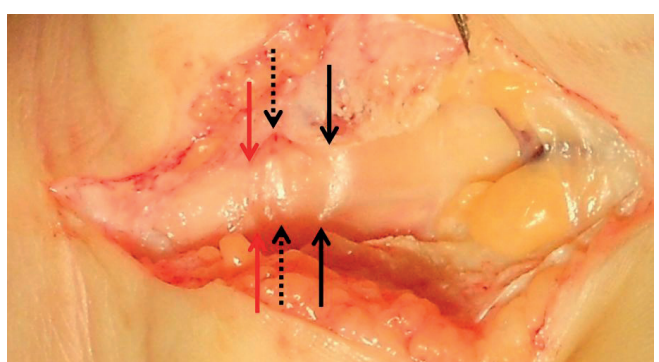

4. a ábra

A retinaculum teljes átmetszése után vált láthatóvá az eredeti leszorítás helye (fekete nyil). A ligamentum carpi volare korábbi behasítása következtében a retinaculum flexorum - így mesterségesen létrehozott - proximalis széle egy további leszorítási vonalat képezett (piros nyil), $s$ az oedemás nervus medianus mintegy "feltorlódott" (szaggatott fekete nyil) a két kompressziós hely között.

\section{Eredmény}

A beteg erős fájdalmai teljesen megszűntek, a szenzibilitás már a mútéttől eltelt 3 hónap alatt javult. Jelenleg enyhe érzékenységet jelez a tenyéri felszínen. A későbbiekben - ha a beteg igényli - opponenspótló íntranspositióra kerülhet sor.

\section{MEGBESZÉLÉS}

Ritkán találkozunk olyan sebészi megbetegedéssel, amelynek mútéti kezelési módszerei közül, több évtized után is a legrégebbi eljárás legyen a legkevesebb szövődménnyel járó, legeredményesebb beavatkozás. A carpal tunnel szindróma eme ritkaság közé sorolható. Bármilyen új módszertől, eljárástól elvárható az a minimális követelmény, hogy ne legyen több szövődménye, ne legyen rosszabb, mint a bevált korábbi módszer.

\section{Az eset kapcsán felmerülö kérdések:}

Miért csak a ligamentum carpi behasítását végezte a sebész?

Egyetlen tankönyv, vagy közlemény sem írja, hogy ez elegendő, minden tudományos publikációban leírt módszer - legyen az bármelyik „minimal invazív” eljárás - a retinaculum transversum flexorum teljes átmetszését célozza. Csak annak a területnek a feltárása, amelyet a leszorítástól proximalisan, az oedematól megvastagodott ideg előboltosít - jelen esetben a ligamentum carpi volare behasítása

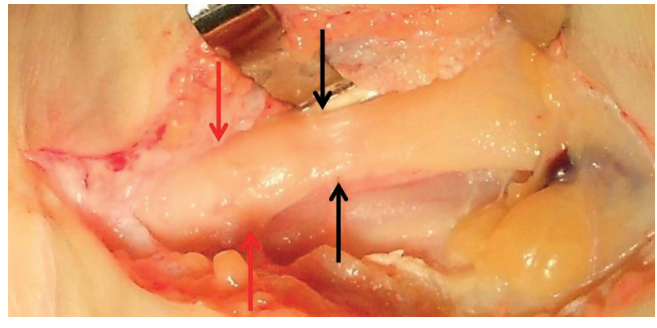

\section{4. $b$ ábra}

A nervus medianus a neurolysis után. Az eredeti leszorítás helye (fekete nyil). A másodlagos leszorítás helye (piros nyíl).
- nem oldja meg a problémát, hiszen a leszorítás -topográfiailag - ettól distalisan van.

Hogyan állapíthatta volna meg - amivel igen gyakran találkozunk - hogy az ideg motoros ága nem szenved-e külön is kompressziót az izomba lépésnél?

A reoperációnál a motoros ág egyáltalán nem volt megtalálható, ami csak úgy lehetséges, hogy az első mútétnél az operáló sebész valamilyen eszközzel, distal felé, fedetten benyúlt az ideg mellé, annak radialis oldalán, s az eszköz definitív károsodást okozott a motoros ágon, anélkül, hogy ezt észlelte volna. Talán a mútétnek ezen szakaszát nevezte „neurolysisnek” a zárójelentésben (?!).

E feltárásból hogyan állapíthatta volna meg, hogy a leszorítás valós környezetében nincs-e excisiót igénylö krónikus synovitis?

\section{KÖVETKEZTETÉS}

Elvárható szakmai minimum, hogy aki ilyen mútétre vállalkozik, teljes értékűen ismerje annak a régiónak az anatómiai felépítését, ahol operál (9), tisztában kell lennie a múlt és jelen mútéti technikáinak gyakorlatával, azok eredményeit, előnyeit és veszélyeit egyaránt ismernie kell. Előzetes tapasztalatszerzés nélkül, (cadaver gyakorlat, tanfolyam) ne vállalkozzon eredményességüket még nem bizonyított, új kezelési eljárások alkalmazására. 
Az eset tanulságaként még egy-két meszszebbre vezető kérdést is fel kell tennünk:

Kinek, kiknek, s milyen körülmények között van jogosultságuk egy adott sebészi módszert alkalmazni? Meddig terjed az orvosi módszerek megválasztásának szabadsága?
Vajon ki szerez érvényt az Ortopéd Szakmai Kollégium felkérésére a Magyar Kézsebész Társaság által 2010-ben elkészített, s az Egészségügyi Közlönyben közzétett Szakmai Protokollnak (21)? Ellenőrzi egyáltalán valaki, hogy azt betartják-e?

\section{IRODALOM}

1. Agee J. M., Mc Carroll H. R., North E. R.: Endoscopic carpal tunnel release using the single proximal incision technique. Hand Clin. 1994. 10. (4): 647-659.

2. Amadio P. C.: History of carpal tunnel syndrome. In Luchetti R., Amadio P. (Eds.): Carpal tunnel syndrome. Berlin etc. Springer, 2007. 3-9. p. https://doi.org/10.1007/978-3-540-49008-1 1

3. Benson L. S., Bare A. A., Nagle D. J., Harder V. S., Williams C. S., Visotsky J. L.: Complications of endoscopic and open carpal tunnel release. Arthroscopy, 2006. 22. (9): 919-924. https://doi.org/10.1016/i.arthro.2006.05.008

4. Bhattacharya R., Birdsall P.D., Finn P., Stothard J.: A randomized controlled trial of knifelight and open carpal tunnel release. J. Hand Surg. Br. 2004. 29. (2): 113-115. https://doi.org/10.1016/i.jhsb.2003.09.001

5. Bíró V.: A carpal tunnel szindróma : irodalmi áttekintés és saját tapasztalatok. Magyar Traumatológia Ortopédia Kézsebészet Plasztikai Sebészet. 2009. 52. (3): 198-207. DOI: 10.21755/MTO.2009.052.0003.001

6. Boeckstyns M. E., Sorensen A. I.: Does endoscopic carpal tunnel release have a higher rate of complications than open carpal tunnel release? An analysis of published series. J. Hand Surg. Br. 1999. 24. (1): 9-15. https://doi.org/10.1016/S0266-7681(99)90009-8

7. Buncke G., McCormack B., Bodor M.: Ultrasound-guided carpal tunnel release using the Manos CTR system. Microsurgery. 2013. 33. (5): 362-366. https://doi.org/10.1002/micr.22092

8. Fajardo M., Kim S. H., Szabo R. M.: Incidence of carpal tunnel release trends and implications within the United States ambulatory care setting. J. Hand Surg. (Am), 2012. 37. (8): 1599-1605. https://doi.org/10.1016/i.jhsa.2012.04.035

9. Godlewski B., Czepko R., Gierula T., Klauz G.: Anatomic aspects of the carpal tunnel release surgery. Austin Neurosurg. Open Access. 2014. 1. (2): 1008.

10. Guo D., Tang Y., Ji Y., Sun T., Guo J., Guo D.: A non-scalpel technique for minimally invasive surgery percutaneously looped thread of the transverse carpal ligament. Hand. 2015. 10: 40-48. https://doi.org/10.1007/s11552-014-9656-4

11. Helm R. H., Vaziri S.: Evaluation of carpal tunnel release using the Knifelight instrument. J Hand. Surg. Br. 2003. 28. (3): 251-254. https://doi.org/10.1016/S0266-7681(02)00395-9

12. Hwang P. Y., Ho, C. L.: Minimally invasive carpal tunnel decompression using the Knifelight. Neurosurgery. 2007. 60. (2 Suppl. 1) ONS162-169. https://doi.org/10.1227/01.NEU.0000249249.33052.7E

13. Karen A. C., Margaret J. H., Aleksandr G.: Ambulatory surgery in the United States, 2006. National Health Statistics Reports Number 11. January 28, 2009.

14. Kómár J.: Alagút szindrómák és egyéb kompressziós mononeuropáthiák. Budapest, White Golden Book. 2002.

15. Korkmaz M., Ekici M. A., Cepoglu M. C., Oztürk H.: Mini trasverse versus longitudinal incision in carpal tunnel syndrome. J. Coll. Physicians Surg. Pak. 2013. 23. (9): 645-648.

16. Learmonth J. R.: The principle of decompression in the treatment of certain diseases of peripheral nerves. Surg. Clin. North Am. 1933. 13: 905-913.

17. Malone D. G., Clark T. B., Wei N.: Ultrasound-guided percutaneous injection, hydrodissection, and fenestration for carpal tunnel syndrome: Description of a new technique. J. App. Res. 2010. 10. (3): 116-123.

18. Markison R. E.: Percutaneous ultrasound-guided MANOS carpal tunnel release technique. Hand. 2013. 8. (4): 445-449. https://doi.org/10.1007/s11552-013-9554-1

19. Mintalucci D. J., Leinberry Jr. C. F.: Open versus endoscopic carpal tunnel release. Orthop. Clin. North. Am. 2012. 43. (4): 431-437. https://doi.org/10.1016/i.ocl.2012.07.012

20. Müller L. P., Rudig L., Blum J., Degreif J.: Complications of endoscopic retinaculum dissection. Handchir. Mikrochir. Plast. Chir. 1997. 29. (5): 238-242.

21. Ortopédiai Szakmai Kollégium: Az Egészségügyi Minisztérium szakmai protokollja. A carpal tunnel szindrómáról (1. módositott változat). Egészségügyi Közlöny. 2010. 21. 3220-3224.

22. Paget J: The first description of carpal tunnel syndrome. J. Hand. Surg. Eur. 2007. 32. (2): $195-197$. https://doi.org/10.1016/J.JHSB.2006.12.010

23. Palmer D. H., Paulson J. C., Lane-Larsen C. L., Peulen V. K., Olson J. D.: Endoscopic carpal tunnel release: a comparison of two techniques with open release. Arthroscopy, 1993. 9. (5): 498-508. https://doi.org/10.1016/S0749-8063(05)80396-2 
24. Pomerance J., Zurakowski D., Fine I.: The cost-effectiveness of non surgical versus surgical treatment for carpal tunnel syndrome. J. Hand Surg. Am. 2009. 34.. (7): 1193-1200. https://doi.org/10.1016/i.jhsa.2009.04.034

25. Rodner C. M., Katarincic J.: Open carpal tunnel release. Tech. Orthop. 2006. 21. (1): 3-11.

26. Sántha E.: Carpal tunnel syndroma. In: Renner A, Sántha E.: A kéz sebészete. Budapest, KADIX-Press, 2014. 326-330. p.

27. Verdugo R. J., Salinas R. A., Castillo J. L., Cea J. G.: Surgical versus non-surgical treatment for carpal tunnel syndrome. Cochrane Data-base Syst. Rev. 2008. (4): CD001552. https://doi.org/10.1002/14651858.CD001552.pub2

\section{Prof. Dr. Renner Antal}

Péterfy Kórház-Rendelőintézet Országos Traumatológiai Intézet

1081 Budapest, Fiumei út 17. 
